\title{
Pemanfaatan Limbah Tahu Untuk Bahan Baku Kerupuk Sebagai Upaya Peningkatan Perekonomian Masyarakat
}

\author{
Deni Arifianto, Qurrota A'yun, Retno Murwanti \\ Universitas Muhammadiyah Jember \\ E-mail:deniarifianto@unmuhjember.ac.id, qurrota.ayun@unmuhjember.ac.id, \\ retnomurwanti@unmuhjember.ac.id
}

Diterima: April 2021 | Dipublikasikan: Juni 2021

\begin{abstract}
ABSTRAK
Banyak pengrajin tahu yang membuang limbah atau ampas tahu begitu saja sehingga dapat menimbulkan pencemaran lingkungan sekitar. Salah satu upaya dalam mengatasi hal tersebut adalah dengan memanfaatkan limbah tahu sebagai aneka olahan pangan yang bernilai jual tinggi. Melihat sifat ampas tahu yang memiliki kandungan gizi seperti protein, lemak dan karbohidrat yang tinggi serta murah dan mudah didapat sehingga berpotensi diolah menjadi produk pangan yang bergizi tinggi. Keterampilan membuat aneka olahan pangan dari ampas tahu dapat dikembangkan untuk meningkatkan pendapatan masyarakat. Mitra kegiatan PKM ini adalah Komunitas Basmallah di Desa Wonosari Kecamatan Puger Kab. Jember. Komunitas Basmallah merupakan perkumpulan ibu-ibu rumah tangga (PKK) yang terdiri dari 15 orang. Pada kegiatan PKM ini diusulkan tiga kegiatan utama yaitu: (1) Penyediaan Teknologi tepat guna yaitu mesin pres ampas tahu dan pemotong kerupuk serta pengemasana menggunakan hand sealer (2) Program pelatihan dan pendampingan pemanfaatan olahan produk ampas tahu, (3) penyediaan dan pendampingan model manajemen usaha yaitu manajemen keuangan yang berstandar akuntansi IKM (Industri Kecil Menengah) dan manajemen pemasaran melalui market place.
\end{abstract}

Kata Kunci: limbah tahu, mesin pres ampas tahu, pemotong kerupuk, menajemen keuangan, manajemen pemasaran

\section{ABSTRACT}

Many tofu craftsmen just dispose of waste or tofu dregs so that it can cause environmental pollution. One of the efforts to overcome this problem is by utilizing tofu waste as a variety of food products with high selling value. the nature of tofu dregs that contain nutrients such as protein, high fat and carbohydrates and are cheap and easy to obtain so that they have the potential to be processed into highly nutritious food products. The skills to make various processed foods from tofu dregs can be developed to increase people's income. This PKM activity partner is the Basmallah Community in Wonosari Village, Puger District, Kab. Jember. The Basmallah Community is an association of housewives (PKK) which consists of 15 people. In this PKM activity, three main activities were proposed, namely: (1) Provision of appropriate technology, namely tofu dregs pressing machine and cracker cutter as well as packaging using a hand sealer (2) Training and assistance programs for the diversification of tofu dregs products, (3) provision and assistance business management model, namely financial management with accounting standards for IKM (Small and Medium Industries) and marketing management through the market place.

Keywords: waste tofu, tofu dregs pressing machine, cracker cutter, financial management, marketing management.

\section{PENDAHULUAN}

Pengrajin tahu di Desa Wonosari Kecamatan Puger Kabupaten Jember sebanyak 20 pengrajin tahu. Rata-rata setiap pengrajin tahu kapasitas produksinya per-hari adalah 1-2 kuintal kedelai impor. Untuk 1 kuintal kedelai menghasilkan 50 papan tahu dengan ampas tahu 10 timba. Jika satu desa memproduksi tahu minimal 1 kuintal kedelai maka ampas tahu yang diperoleh untuk satu desa adalah $20 \times 10$ timba $=200$ timba perhari untuk satu desa. Harga jual per-kilo ampas tahu adalah Rp.300-500. Lima dari 20 pengrajin tahu memproduksi ampas tahu sebagai tempe gembus, sedangkan sisanya dijual sebagai pakan ternak sapi dan sebagian di buang karena pemilik 
ternak di desa wonosari tidak sebanding dengan banyaknya pengrajin tahu. Limbah tahu yang dibuang oleh pengrajin akan menimbulkan pencemaran lingkungan karena aromanya yang menyengat. Hal ini yang menjadi keluhan warga di desa Wonosari. Salah satu upaya dalam mengatasi hal tersebut adalah dengan memanfaatkan limbah tahu sebagai aneka olahan pangan yang bernilai jual tinggi.

Komunitas Basmallah merupakan perkumpulan ibu-ibu rumah tangga (PKK) yang jumlahnya 15 orang dengan usianya yang produktif yaitu 25-50 tahun dan mampu melakukan banyak hal yang dapat membantu perekonomian keluarga. Selama ini mereka belum tahu dan menyadari jika ampas tahu dapat diolah menjadi aneka olahan pangan yang enak dan bergizi dengan nilai jual tinggi. Oleh karenanya, ketika ibu-ibu mendapatkan informasi sekilas tentang potensi ampas tahu dan proses pengolahannya yang mudah, mereka sangat tertarik untuk bisa diberi edukasi dan pelatihan tentang teknologi dan keterampilan pembuatan aneka olahan makan dari ampas tahu. Menurut mereka, selain menjadi solusi terhadap permasalahan limbah ampas tahu yang menimbulkan pencemaran dilingkungannya, hal ini juga dijadikan kegiatan produktif yang dapat dikembangkan sebagai peluang usaha oleh para ibu-ibu di lingkungannya.

Alternatif pemanfaatan ampas tahu untuk diversifikasi aneka olahan pangan akan lebih menguntungkan, karena lebih ekonomis dan membantu pengusaha tahu dalam penanganan limbahnya untuk mewujudkan industri ramah lingkungan. Selain itu, protein dan lemak yang masih tersisa dalam ampas tahu diharapkan dapat meningkatkan kandungan gizi aneka olahan pangan. Ampas tahu juga memiliki kadar serat total yang tinggi, yaitu $28,4 \%$. Kebutuhan serat makanan manusia adalah sekitar $38 \mathrm{~g} /$ hari untuk laki-laki dan $25 \mathrm{~g} / \mathrm{hari}$ untuk perempuan (FAO/WHO Expert Consultation 2002; Simsek dan Sedef 2012). Sehingga masih dapat dimanfaatkan lagi untuk olahan pangan (Rusdi, Maulana, dan Kodir, 2013)

Berdasarkan analisis situasi, maka dapat dirumuskan tiga permasalahan prioritas sebagai berikut: (a) Belum adanya pengetahuan dan keterampilan dalam pengolahan limbah (ampas) tahu menjadi produk hasil olahan bernilai jual tinggi, (b) Belum adanya mesin pres ampas tahu yaitu memisahkan ampas tahu dengan kadar airnya dan mesin dalam pemotongan kerupuk yaitu untuk menjaga ketebalan kerupuk yang sama. (c) Belum ada pengelolaan manajemen penjualan yang berkaitan dengan keuangan dan pemasaran dengan menggunakan teknologi informasi untuk meningkatkan daya saing produk.

Adapun tujuan kegiatan pada program kemitraan masyarakat ini adalah:

1. Memberikan pelatihan dan keterampilan dalam pengolahan limbah (ampas) tahu menjadi produk hasil olahan bernilai jual tinggi

2. Penyedian teknologi tepat guna seperti press ampas tahu yaitu memisahkan ampas tahu dengan kadar airnya dan mesin dalam pemotongan kerupuk yaitu untuk menjaga ketebalan kerupuk yang sama.

3. Memberikan pelatihan dan pendampingan pengelolaan manajemen penjualan yang berkaitan dengan keuangan dan pemasaran dengan menggunakan teknologi informasi untuk meningkatkan daya saing produk.

\section{METODE PELAKSANAAN}

Berdasarkan solusi dan target luaran yang diusulkan dalam kegiatan Program Kemitraan Masyarakat (PKM) ini, maka diuraikan tahapan dalam melaksanakan solusi pada bidang kegiatan produksi yang ditunjukkan dalam Tabel 1. Sedangkan kegiatan manajemen keuangan ditunjukkan dalam Tabel 2 dan manajemen pemasaran melalui market place ditunjukkan dalam Tabel 3. 
Tabel 1. Tahapan kegiatan produksi

\begin{tabular}{|l|l|l|l|}
\hline \multicolumn{1}{|c|}{ Masalah } & \multicolumn{1}{|c|}{ Solusi } & \multicolumn{1}{c|}{ Luaran } & \multicolumn{1}{c|}{ Tahapan } \\
\hline $\begin{array}{l}\text { Kesulitan } \\
\text { untuk dapat } \\
\text { memulai } \\
\text { proses } \\
\text { produksi } \\
\text { karena } \\
\text { kurangnya } \\
\text { tenaga / } \\
\text { SDM }\end{array}$ & $\begin{array}{l}\text { Penyediaan } \\
\text { pendampingan } \\
\text { penerapan } \\
\text { Teknologi } \\
\text { Tepat Guna }\end{array}$ & $\begin{array}{l}\text { Tersedianya } \\
\text { mesin pres ampas } \\
\text { tahu dan } \\
\text { pemotong } \\
\text { kerupuk serta } \\
\text { panduan manual } \\
\text { pengoperasiannya }\end{array}$ & $\begin{array}{l}\text { 1. Pembelian mesin pres ampas tahu } \\
\text { dan pemotong kerupuk } \\
\text { 2. Pengujian kualitas hasil pres ampas } \\
\text { tahu dengan limbah cairnya }\end{array}$ \\
$\begin{array}{l}\text { 3. Pengujian mesin pemotong kerupuk } \\
\text { 4. Membuat SOP pengoperasian cara } \\
\text { kerja mesin }\end{array}$ \\
\cline { 3 - 4 }
\end{tabular}

Dalam program penyediaan Teknologi Tepat Guna (TTG). Tim pengusul bertindak sebagai (1) penyedia dan memilih teknologi yang akan dipakai dalam kegiatan pembuatan olahan tahu, (2) pengujian performa kedua mesin (3) pembuat dokumen SOP. Mitra bertindak sebagai penyedia informasi mengenai kapasitas produksi, jadwal produksi, dan kelayakan hasil produksi. Mitra juga berperan sebagai peserta pelatihan dan pendampingan penggunaan mesin. 
Tabel 2. Tahapan kegiatan manajemen keuangan

\begin{tabular}{|c|c|c|c|}
\hline Masalah & ddSolusi & Luaran & Tahapan \\
\hline \multirow[t]{2}{*}{$\begin{array}{l}\text { Kurangnya } \\
\text { pengetahuan } \\
\text { dan } \\
\text { ketrampilan } \\
\text { dalam } \\
\text { melakukan } \\
\text { manajemen } \\
\text { keuns }\end{array}$} & \multirow[t]{2}{*}{$\begin{array}{l}\text { Pelatihan dan } \\
\text { pendampingan } \\
\text { manajemen } \\
\text { keuangan usaha } \\
\text { kecil }\end{array}$} & $\begin{array}{l}\text { Pengetahuan } \\
\text { dan } \\
\text { keterampilan } \\
\text { manajemen } \\
\text { keuangan } \\
\text { usaha kecil }\end{array}$ & $\begin{array}{l}\text { 1. Persiapan lokasi } \\
\text { pelatihan/pendampingan dan } \\
\text { persiapan bahan dan alat produksi di } \\
\text { lokasi mitra } \\
\text { 2. Penyampaian materi mengenai } \\
\text { manajemen keuangan usaha kecil } \\
\text { 3. Pendampingan penerapan manajemen } \\
\text { keuangan untuk memastikan usaha } \\
\text { berjalan dengan lancar }\end{array}$ \\
\hline & & $\begin{array}{l}\text { Pembukuan } \\
\text { administrasi } \\
\text { keuangan } \\
\text { usaha kecil }\end{array}$ & $\begin{array}{l}\text { 1. Membuat standar pencatatan transaksi } \\
\text { cash in / cash out } \\
\text { 2. Mendampingi pembuatan laporan } \\
\text { keuangan usaha }\end{array}$ \\
\hline
\end{tabular}

Dalam program pelatihan dan pendampingan manajemen keuangan usaha kecil, Tim pengusul berperan sebagai (1) Pemateri dalam pelatihan mengenai manajemen keuangan usaha kecil, (2) Pendamping atau mentor dalam pendampingan penerapan manajemen keuangan untuk memastikan usaha berjalan dengan lancar, dan (3) Pembuat standar pencatatan transaksi uang masuk dan uang keluar dan mendampingi dalam pembuatan laporan keuangan. Mitra komunitas Basmalah berperan sebagai peserta dalam manajemen keuangan usaha kecil

Tabel 3. Tahapan kegiatan PKM bidang pemasaran

\begin{tabular}{|c|c|c|c|}
\hline Masalah & Solusi & Luaran & Tahapan \\
\hline \multirow[t]{3}{*}{$\begin{array}{l}\text { Urangnya } \\
\text { pengetahuan } \\
\text { masyaraat } \\
\text { tentang } \\
\text { pemasaran } \\
\text { melalui } \\
\text { marketplae }\end{array}$} & \multirow[t]{3}{*}{$\begin{array}{l}\text { Pelatihan dan } \\
\text { pendampingan } \\
\text { pemasaran } \\
\text { melalui market } \\
\text { place }\end{array}$} & $\begin{array}{l}\text { Tersedianya } \\
\text { toko online } \\
\text { menggunakan } \\
\text { marketplace }\end{array}$ & $\begin{array}{ll}\text { 1. Pendaftaran toko online di } \\
\text { beberapa market place nasional. } \\
\text { 2. } \\
\text { Verifikasi dan validasi layanan } \\
\text { atau fitur utama keuangan dan } \\
\text { pemasaran serta fitur penunjang. } \\
\text { 3. Pembuatan dokumen SOP } \\
\text { berdasarkan langkah-langkah yang } \\
\text { dibutuhkan untuk masing-masing } \\
\text { market place yang digunakan. }\end{array}$ \\
\hline & & $\begin{array}{l}\text { Pengetahuan } \\
\text { dan } \\
\text { keterampilan } \\
\text { pengoperasian } \\
\text { market place } \\
\end{array}$ & $\begin{array}{l}\text { 1. pelatihan dan sosialisasi toko } \\
\text { online } \\
\text { 2. Pendampingan praktek } \\
\text { pengoperasian toko online selama } \\
\text { pelaksanaan program PKM. }\end{array}$ \\
\hline & & Unit usaha kecil & $\begin{array}{l}\text { 1. Pendampingan penerapan } \\
\text { pemasaran melalui market place } \\
\text { pasca pelatihan untuk memastikan } \\
\text { usaha berjalan dengan lancar } \\
\text { 2. Menghasilkan profit selama } \\
\text { pelaksanaan program PKM. } \\
\text { 3. Konsultan pengembangan strategi } \\
\text { pemasaran }\end{array}$ \\
\hline
\end{tabular}

Dalam program pelatihan dan pendampingan pemasaran market place. Tim Pengusul bertindak sebagai (1) Perancang toko online di beberapa market place nasional, (2) Verifikasi dan validasi layanan atau fitur utama pemasaran serta fitur penunjangnya, (3) Pembuatan dokumen SOP berdasarkan langkah-langkah yang dibutuhkan untuk masing-masing market place yang 
digunakan., (4) Pelatih dan pendamping kegiatan pelatihan dan praktek pengoperasian SIM selama pelaksanaan program PKM, dan (5) Konsultan pengembangan strategi pemasaran.

\section{HASIL KEGIATAN}

Pada Program Kemitraan Masyarakat (PKM) ini telah dilakukan kegiatan yang meliputi persiapan, penyusunan standar operasi prosedur (SOP), pengujian mesin pemeras ampas tahu dan pemotong kerupuk, serta kegiatan pelatihan dan pendampingan praktek produksi pemanfaatan ampas tahu. Berikut ini merupakan beberapa kegiatan yang telah dilakukan pada Program Kemitraan Masyarakat Tahun 2020.

\section{Kegiatan pesiapan}

Tim pelaksana PKM melakukan Rapat koordinasi antar anggota Tim. Tujuan kegiatan koordinasi ini adalah survey lapanagan dan menyusun rencana kegiatan pengabdian yang akan dilakukan serta pembagian tugas. Koordinasi ini dilakukan pada tanggal 22 Juni 2020. Dari hasil koordinasi menghasilkan (1) pembagian tugas selama kegiatan, (2) merencankan inti-inti yang harus dilakukan semala kegiatan

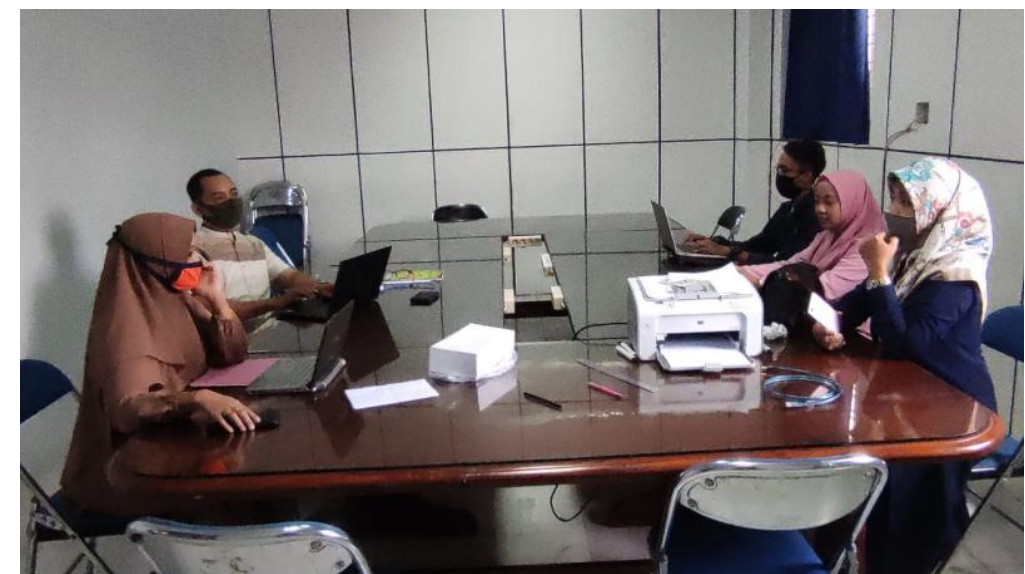

\section{Koordinasi Tim Pelaksana dengan Mitra}

Gambar 1. Rapat koordinasi tim pelaksana program Kemitraan Masyarkat

Setelah melakukan koordinasi antar anggota Tim, maka dilakukan koordinasi antar seluruh Tim pelaksana PKM dengan mitra sasaran yaitu Komunitas Basmallah yang dilakukan sejak tanggal 24 Juni 2020. Adapun hasil kesepakatan dari koordinasi Tim Pelaksna dengan Mitra adalah (1) mitra bersedia mempersiapkan kebutuhan penunjang untuk persiapan produksi , (2) lokasi mitra cukup luas sehingga alat bisa di taruh, (3) mendiskusikan rancangan kegiatan yang akan dilakukan selama kegiatan PKM diantaranya yaitu berupa pelatihan produksi olahan ampas tahu dan pengemasannya, penerapan menajemen keuangan dan cara pemasarannya menggunakan marketplace. 
Berikut akan diuraikan hasil koordinasi antara Tim Pelaksana dengan Mitra. Secara lengkap akan disajikan pada Tabel 3

Tabel 3 Jadwal dan Uraian Kegiatan PKM 2020

\begin{tabular}{|l|l|l|}
\hline No. & \multicolumn{1}{|c|}{ Tanggal } & \multicolumn{1}{c|}{ Uraian Kegiatan PKM } \\
\hline 1 & Juni 2020 & $\begin{array}{l}\text { Rapat Koordinasi dengan Tim pelaksanaan persiapan survey } \\
\text { lapangan dan koordinasi tempat pemesanan mesin }\end{array}$ \\
\hline 3 & Juni - Juli 2020 & $\begin{array}{l}\text { Penyusunan Dokumen Standar Operasional (SOP) dan modul } \\
\text { pelatihan produksi olahan ampas tahu }\end{array}$ \\
\hline 5 & Juli 2020 & $\begin{array}{l}\text { Pengujian mesin press ampas tahu dan pemotong krupuk } \\
\text { serta serah terima mesin kepada mitra }\end{array}$ \\
\hline 8 & Juli 2020 & $\begin{array}{l}\text { Pelatihan dan pendampingan produksi olahan ampas tahu } \\
\text { dan pengemasan produk }\end{array}$ \\
\hline 10 & Agustus 2020 & $\begin{array}{l}\text { Pelatihan dan pendampingan penerapan manajemen } \\
\text { keuangan untuk memastikan usaha berjalan dengan lancar } \\
\text { dan pendampingan dalam pengemasan kerupuk }\end{array}$ \\
\hline 11 & Agustus 2020 & $\begin{array}{l}\text { Pelatihan dan pendampingan strategi pemasaran untuk } \\
\text { produk yang telah dihasilkan melalui marketplace }\end{array}$ \\
\hline 12 & September 2020 & $\begin{array}{l}\text { Monitoring hasil produk yang telah dibuat sekaligus } \\
\text { pemasarannya }\end{array}$ \\
\hline
\end{tabular}

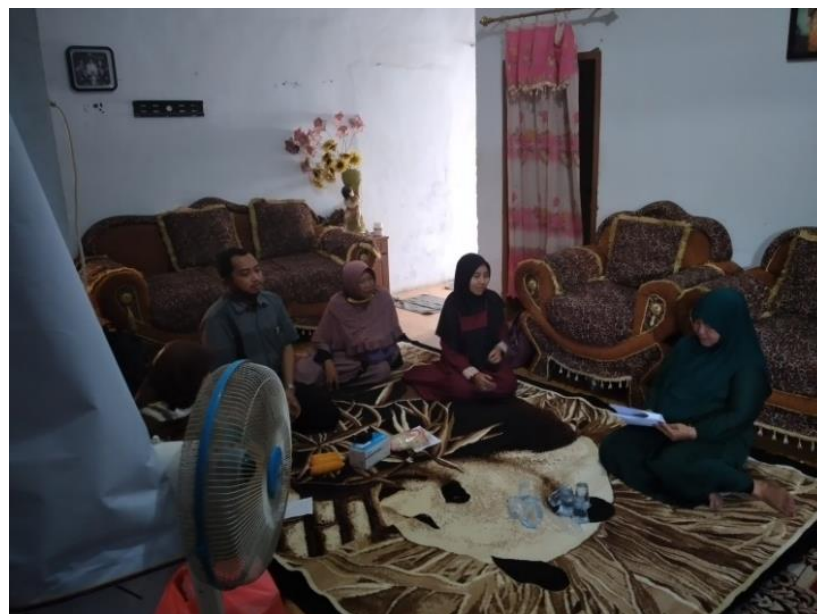

Gambar 2. Koordinasi Tim Pelaksana dengan mitra PKM

\section{Penyususnan Standar Operasi Prosedur (SOP)}

Pada kegiatan ini akan dilakukan penyusunan SOP produksi dan modul pelatihan

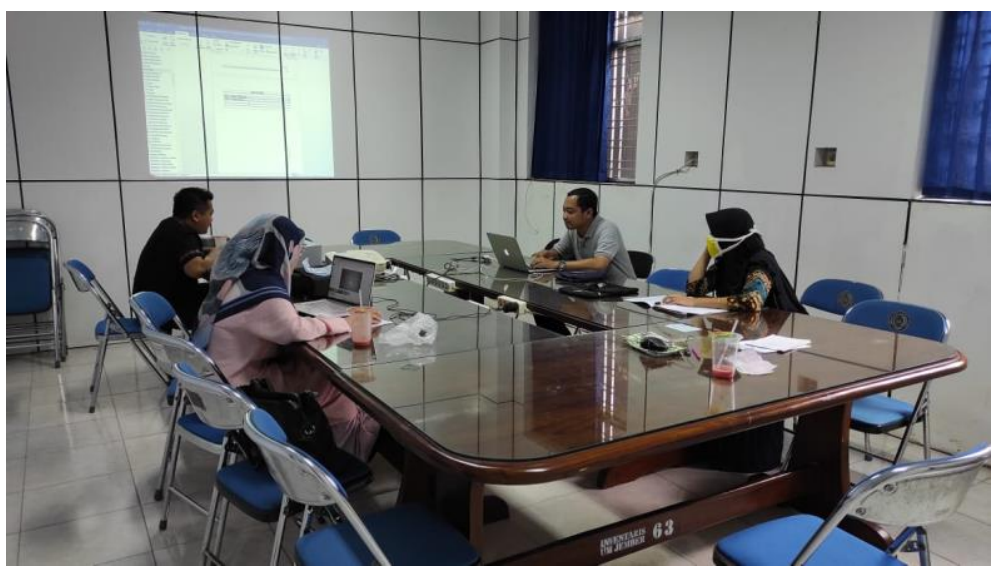

Gambar 3. Penyusunan SOP produksi dan modul pelatihan 
Pada kegiatan ini dihasilkan beberapa catatan yaitu (1) SOP produksi alat masih selsai sekitar 50\% yang nantinya SOP ini akan didiskusikan dengan orang yang membuat mesin, dan (2) modul varian rasa pada kerupuk yang akan diproduksi berupa rasa ikan. Dikarenakan desa wonosari dekat dengan pelabuhan ikan. Sehingga mudah mendapatkan ikan.

\section{Uji Coba Mesin dan Serah Terima Mesin Kepada Mitra}

Sebelum mesin siap digunakan tentu saja pengujian mesin. Pengujian mesin dilakukan di lokasi mitra dengan tujuan mempersiapkan mesin dan semua peralatan terpasang dengan baik. Sehingga ketika proses produksi dimulai tidak ada kendala yang muncul.

Tim pelaksana PKM melakukan serah terima mesin kepada Mitra. Mesin yang dimaksud merupakan satu set mesin press ampas tahu, satu set pemotong kerupuk dan dua set hand sealer untuk pengemasan hasil produksi diversivikasi ampas tahu

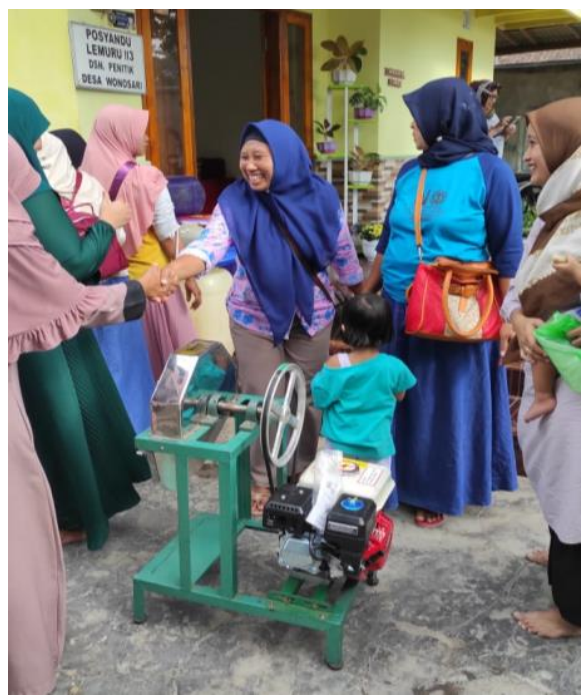

Gambar 4. Uji Coba Mesin dan serah terima

\section{Pelatihan dan pendampingan}

Kegiatan pelatihan dan pendampinagan dilaksanakan 25 Juli 2020 pukul 09.00 WIB bertempat di kediaman ibu Jumaiyah selaku ketua Komunitas Basmallah. Kegiatan ini dibagi menjadi 3 sesi yaitu pengenalan pengenalan teori mengenai pemakaian alat oleh ketua tim (Deni Arifianto), pengenalan olahan ampas tahu yang mempunyai nilai jual tinggi oleh anggota 1 (Qurrota A'yun) dan kegiatan terkhir adalah kegiatan praktik yang didampingi oleh seluruh tim. Peserta yang hadir pada kegiatan ini terdiri dari 20 orang diantaranya anggota Komunitas Basmallah, kitar, warga sedan distributor kerupuk.

Berikut ini merupakan gambar dari kegiatan pelatihan pendampingan Program Kemitraan Masyarakat pada Komunitas Basmallah

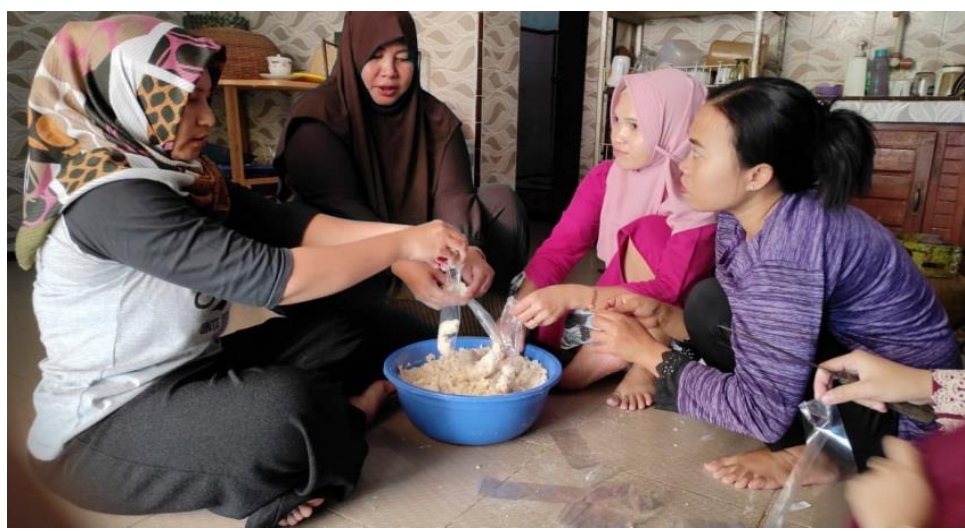

Gambar 5. Kegiatan Praktek pembuatan kerupuk 


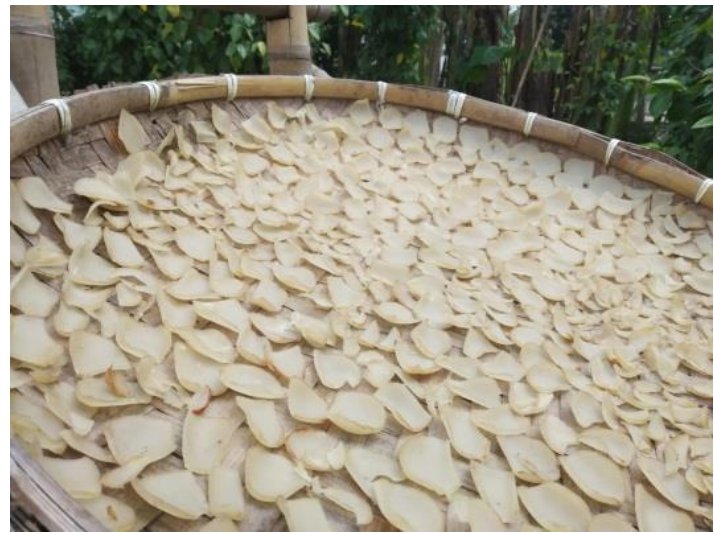

Gambar 6. Hasil Produksi Ampas Tahu Menjadi Kerupuk

Pada tanggal 28 Juli 2020 diadakan pelatihan dan pendampingan pengemasan produk. Dengan tujuan produksi yang dihasilkan mempunyai daya tarik dan bernilai jual tinggi. Pelatihan pengemasan ini dilakukan setelah hasil produksi dijemur dan digoreng.

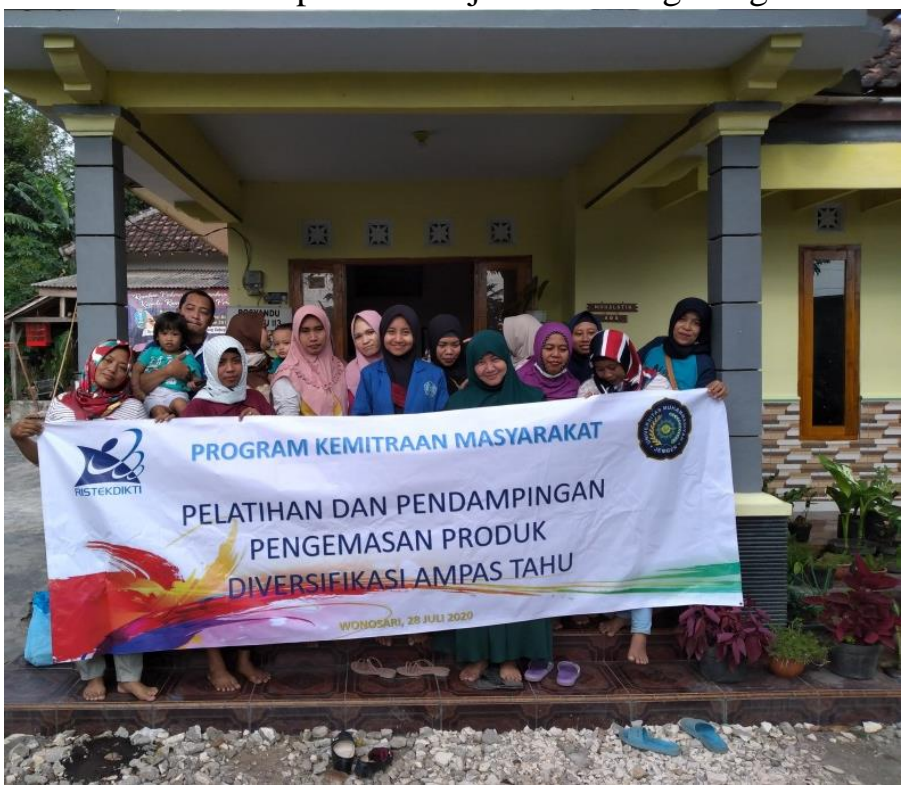

Gambar 7. Peserta pelatihan pengemasan

Keluaran yang dicapai setelah penyediaan teknologi tepat guna berupa mesin pres ampas tahu dan pemotong kerupuk dengan diadakannya pelatihan produksi pemanfaatan ampas tahu dan pelatihan pengemasan produk yaitu kerupuk ampas tahu dengan berbagai varian rasa yang mempunyai nilai jual tinggi.
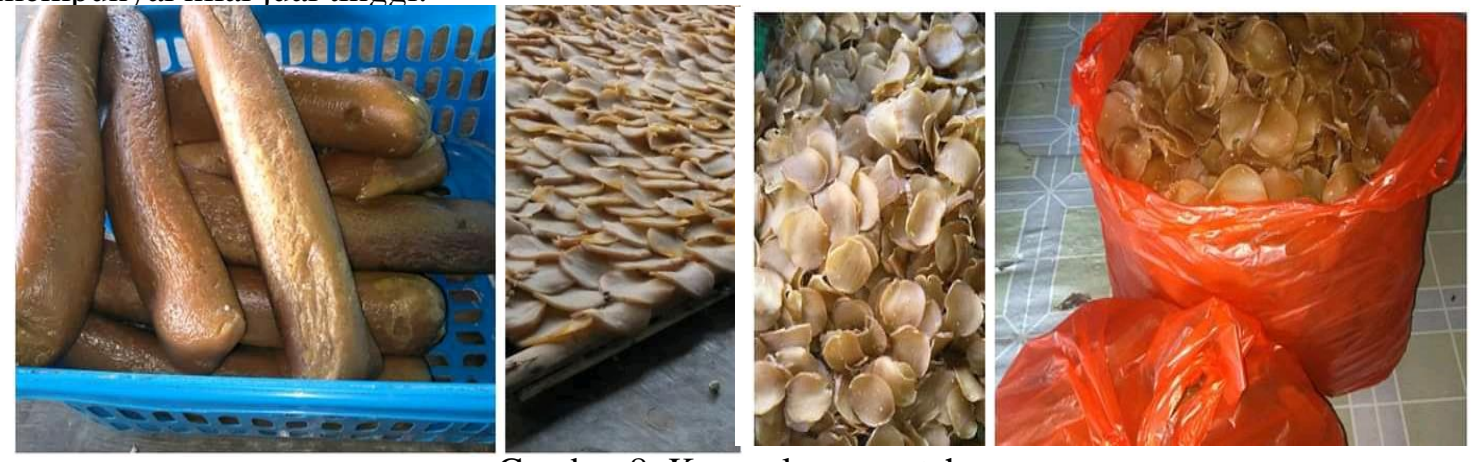

Gambar 8. Kerupuk ampas tahu

Setelah proses penjemuran selesai maka kerupuk siap untuk digoreng dan dikemas. Berikut adalah kemasan kerupuk yang telah di goreng. 


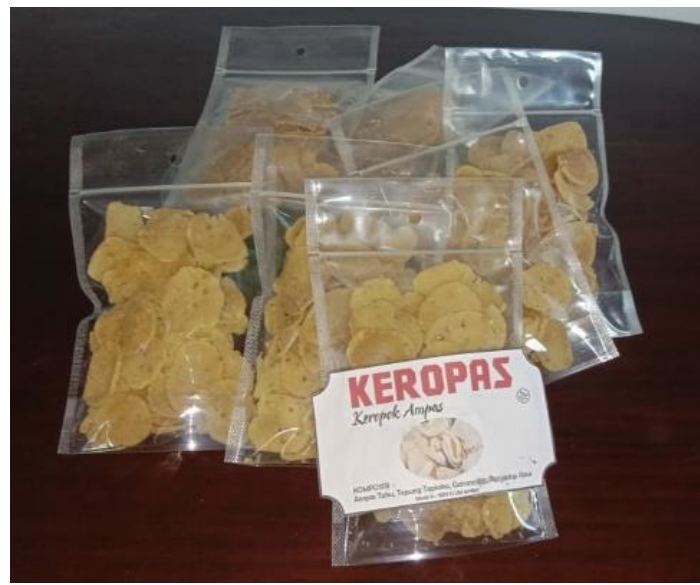

Gambar 9. Produk kemasan

\section{Pelatihan dan pendampingan manajemen keuangan}

Pada kegiatan ini, pelaksana menjelaskan tentang manajemnen keuangan yang diikuti oleh 15 peserta. Kegiatan ini bertempat di rumah ketua komunitas basmallah. Yaitu di desa wonosari, kec. Puger, Kab. Jember.

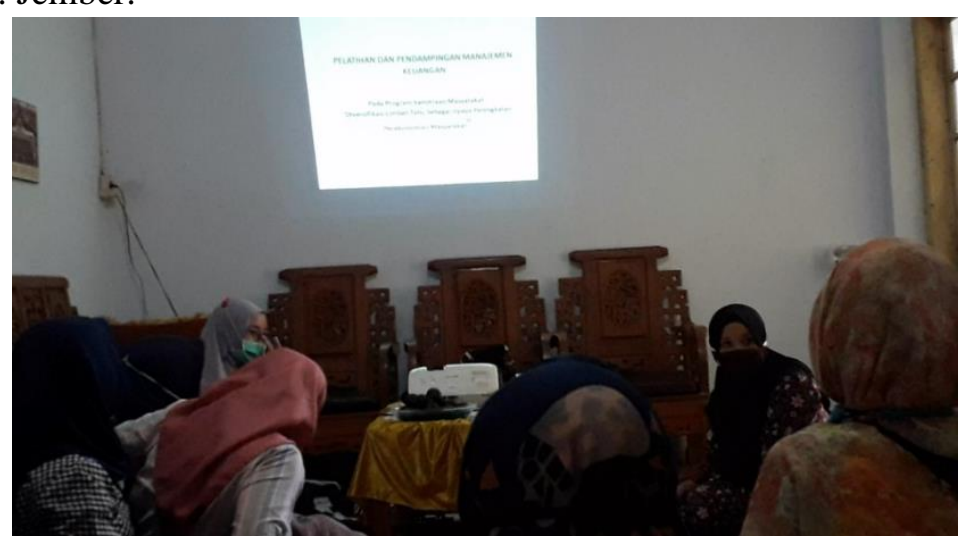

Gambar 10. Pelatihan dan pendampingan manajemen keuangan

\section{Pelatihan dan pendampingan manajemen pemasaran}

Setelah dilakukan pendampingan manajemen keuangan maka kegiatan selanjutnya adalah manajemen pemasaran. Yang bertempat di rumah ketua komunitas basmallah. Jumlah peserta yang datang adalah 15 orang.

Pada kegiatan tersebut diberikan pelatihan strategi pemasaran yang efektif, sebelumnya pemateri menjelaskan marketplace yang paling banyak orang gunakan. Seperti shopee dan tokopedia, mengingat keduanya merupakan marketplace dengan pengguna terbanyak khususnya di Indonesia.

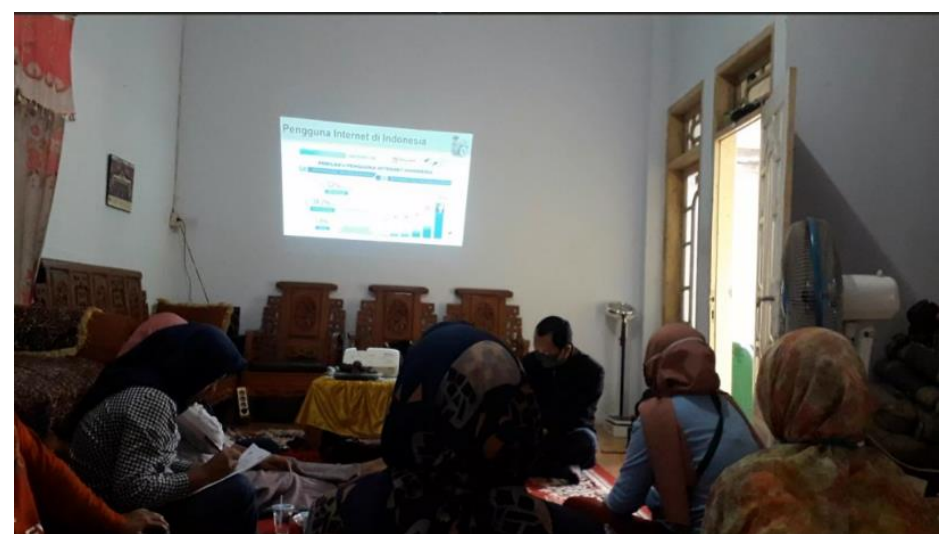

Gambar 11. Pelatihan dan pendampingan manjemen pemasaran 


\section{KESIMPULAN DAN SARAN}

Program Kemitraan Masyarakat (PKM) 2019 dengan judul "Pemanfaatan Limbah Tahu untuk bahan baku kerupuk Sebagai Upaya Peningkatan Perekonomian Masyarakat" secara garis besar telah melaksanakan sebagai berikut:

1. Pelaksana telah melakukan sosialisi kepada Mitra PKM mengenai kegiatan yang akan diadakan berupa pelatihan dan pendampingan diversivikasi limbah tahu yang diikuti oleh 20 peserta yang terdiri dari anggota komunitas basmallah, warga sekitar, dan distributor kerupuk dengan baik dan lancar sesuai dengan rencana yang telah disusun sebelumnya.

2. Telah diberikan teknologi tepat guna seperti press ampas tahu yaitu memisahkan ampas tahu dengan kadar airnya dan mesin dalam pemotongan kerupuk yaitu untuk menjaga ketebalan kerupuk yang sama.

3. Kegiatan produksi kerupuk meningkat dengan adanya mesin pemeras dan pemotong kerupuk. Hal ini diikuti oleh berkurangnya limbah tahu, sehingga kegiatan PKM ini dapat mengurangi pencemaran lingkungan serta memberikan pengalaman dan kemampuan dalam hal berbinis kerupuk.

\section{UCAPAN TERIMAKASIH}

Ucapan terimakasih kami sampai kepada pihak-pihak yang telah mendukung terlaksananya kegiatan Program Kemitraan Masyarakat (PKM) dengan Judul "Pemanfaatan Limbah Tahu untuk bahan baku kerupuk Sebagai Upaya Peningkatan Perekonomian Masyarakat". Berikut ini beberapa pihak-pihak yang telah mendukung acara tersebut:

1. Kemenristek Dikti Republik Indonesia yang telah mendukung baik dana dan pembinaan, sehingga kegiatan seluruh kegiatan dalam program kemitraan ini berjalan lancar;

2. LPPM (Lembaga Penelitian dan Pengabdian Masyarakat) Universitas Muhammadiyah Jember yang telah memberikan pembinaan agar kegiatan ini berlansung dengan baik;

3. Universitas Muhammadiyah Jember dan semua pihak yang telibat dalam Kegiatan PKM.

\section{DAFTAR PUSTAKA}

Rusdi, B., I.T Maulana dan R.A. Kodir. 2013. Analisis Kualitas Tepung Ampas Tahu. Jurnal Matematika \& Sains. 18(2): 57-69 